Polish Journal of Microbiology

2011, Vol. 60, No 2, 175-178

SHORT COMMUNICATION

\title{
Host Response to the Presence of Helicobacter spp. DNA in the Liver of Patients with Chronic Liver Diseases
}

\author{
MAGDA RYBICKA ${ }^{1}$, JOANNA NAKONIECZNA ${ }^{1, *}$, PIOTR STALKE 2 \\ and KRZYSZTOF PIOTR BIELAWSKI ${ }^{1}$
}

${ }^{1}$ Intercollegiate Faculty of Biotechnology, University of Gdańsk and Medical University of Gdańsk, Poland

${ }^{2}$ Department of Infectious Diseases, Medical University of Gdańsk, Gdańsk, Poland

Received 1 December 2010, revised 18 January 2011, accepted 25 January 2011

\author{
Abstract
}

Literature data indicate an association between the presence of Helicobacter spp. in the liver and the development of hepatocellular carcinoma (HCC). However, the role of H. pylori infections in chronic liver diseases (CLD) remains controversial. The aim of this study was to detect Helicobacter spp. DNA in patients with CLD, and to investigate the host response to the presence of the bacterium in the liver. Helicobacter spp. DNA was detected in 59\% samples. H.pylori was the most prevalent species (94\%). We estimated the expression level of IL-1 and IL-8 genes. The presence of Helicobacter spp. did not have a significant effect on the gene expression of IL-8 and IL-1.

Key words: Helicobacter, interleukin 1, interleukin 8, nested-PCR

On the basis of various epidemiological studies H. pylori has been classified as a type I carcinogen by the Working Group of the World Health Organization International Agency for Research on Cancer in 1994 (IARC 1994). H. pylori is specialized in colonizing human gastric mucosa of more than $50 \%$ of world population. It can be a cause of chronic gastritis, peptic ulcers, and gastric adenocarcinoma (Wedi et al., 2002). The bacterium has also been implicated in extra-gastric conditions such as ischemic heart disease, vascular and immunological disorders, halitosis, migraine, and poor growth in children (Pellicano et al., 2008). Recently, Helicobacter spp. DNA has been found in the liver of patients with various chronic liver diseases, such as primary sclerosing cholangitis, hepatocellular carcinoma (HCC), hepatitis $\mathrm{C}$ virus-related chronic infection, and cirrhosis. Inflammatory disease is characterized by increased levels of pro-inflammatory cytokines, such as interleukins 1 and 8 (IL-1 and IL-8). The higher prevalence of Helicobacter spp. associated with more advanced stages of the liver disease supports the possibility of their role in the progression of chronic hepatitis towards cirrhosis and HCC (Pellicano et al., 2008).

In this study we aimed at detecting Helicobacter spp. genetic material in patients with chronic liver diseases in the population of Northern Poland. Further, the host response to the presence of Helicobacter spp. in the liver was investigated.

The study included 27 patients suffering from different chronic liver diseases (CLD): Hepatitis B (HBV) and $\mathrm{C}(\mathrm{HCV})$ virus infections, $\mathrm{HBV} / \mathrm{HCV}$ double infection, non-alcoholic steatohepatitis, non-alcoholic fatty liver disease with $\mathrm{HCV}$ infection, non-alcoholic fatty liver disease with HBV infection, hereditary hemochromatosis, alcoholic steatohepatitis and autoimmunohepatitis. The biopsy from each patient was halved, and used for DNA and RNA extraction, respectively.

DNA was extracted using a High Pure PCR Template Preparation Kit (Roche). Twenty-seven DNA samples with high quality and quantity were amplified. Helicobacter spp. DNA was detected by nested polymerase chain reaction with genus specific primers targeting Helicobacter spp. 16S rRNA gene. The reaction mixture for the first step contained $(25 \mu \mathrm{l}): 100 \mathrm{ng}$ of genomic DNA, $1 \mathrm{x}$ chelating buffer, $2.5 \mathrm{mM} \mathrm{Mg}(\mathrm{OAc})_{2}, 0.2 \mathrm{mM}$ dNTP, $0.4 \mathrm{U}$ of Taq DNA polymerase (Fermentas), $0.1 \mathrm{mg} / \mathrm{ml}$ of casein, $0.01 \%(\mathrm{v} / \mathrm{v})$ formamide and $0.125 \mu \mathrm{M}$ of primers: 1F and 1R (Al-Soud et al., 2003). Amplification conditions for the first PCR were: $94^{\circ} \mathrm{C}$ for $2 \mathrm{~min}$; then 30 cycles of $94^{\circ} \mathrm{C}$ for $30 \mathrm{~s}, 55^{\circ} \mathrm{C}$ for $30 \mathrm{~s}, 72^{\circ} \mathrm{C}$ for $30 \mathrm{~s}$; and finally $72^{\circ} \mathrm{C}$ for $5 \mathrm{~min}$. The reaction mixture for the second step $(25 \mu \mathrm{l})$ contained: $1 \mathrm{x}$ chelating

\footnotetext{
* Corresponding author: J. Nakonieczna, Intercollegiate Faculty of Biotechnology, University of Gdańsk and Medical University of Gdańsk, Poland; Kladki 24, 80-822 Gdańsk, Poland; phone: 4858 5236332; e-mail: strzala@biotech.ug.gda.pl
} 
Table I

Results of liver function test, blood morphology and expression of interleukin 1 and 8 in liver in patients with CLD

\begin{tabular}{|l|c|c|c|c|}
\hline & Helicobacter positive & Helicobacter negative & Range & $\mathrm{P}^{*}$ \\
\hline ALT (alanine aminotransferase) [IU/L] & $80.73 \pm 107.5$ & $83 \pm 78.8$ & $10-409$ & 0.45 \\
\hline AST (aspartate aminotransferase) [IU/L] & $59.26 \pm 77.31$ & $51.4 \pm 39.92$ & $12-316$ & 0.62 \\
\hline ALP (alkaline phosphatase) [IU/L] & $97 \pm 45.72$ & $87.6 \pm 61.5$ & $29-212$ & 0.42 \\
\hline GGTP $(\gamma$-glutamyl transpeptidase) [IU/L] & $108.53 \pm 164.82$ & $178.5 \pm 208.86$ & $9-707$ & 0.2 \\
\hline HGB (hemoglobin) [mg/dL] & $13.58 \pm 1.88$ & $0.77 \pm 0.34$ & $0.24-2.31$ & 0.49 \\
\hline Bilirubin [mg/dL] & $0.94 \pm 0.61$ & $0.86 \pm 0.44$ & $0.24-2.31$ & 1 \\
\hline Liver biopsy grading & $1 \pm 0.83$ & $0 \pm 0.52$ & $0-3$ & 0.13 \\
\hline Liver biopsy staging & $0.47 \pm 0.74$ & $0.5 \pm 1.08$ & $0-3$ & 0.66 \\
\hline IL-8 relative expression (in arbitrary units) & $1.1 \pm 0.9$ & $1.3 \pm 2.5$ & $0-6$ & 0.35 \\
\hline IL-1 relative expression (in arbitrary units) & $27 \pm 66.1$ & $16 \pm 31.4$ & $0.12-259$ & 0.62 \\
\hline
\end{tabular}

$\mathrm{P}^{\star}$ Statistical significance was assessed by U Mann-Whitney Test

buffer, $2.5 \mathrm{mM} \mathrm{MgCl}, 0.2 \mathrm{mM}$ dNTP, $2.5 \mathrm{U}$ of AmpliTaq Gold polymerase, $0.25 \%$ (v/v) glycerol, $0.4 \%(\mathrm{v} / \mathrm{v})$ BSA, $0.125 \mu \mathrm{M}$ of primers: 2F (5'-AGGGAATATTGCTCAATGGG-3', designed by the authors) and 2R (Al-Soud et al., 2003), and $1 \mu \mathrm{l}$ of the first amplification step product. Amplification conditions were: $95^{\circ} \mathrm{C}$ for $10 \mathrm{~min}$; than 35 cycles of $94^{\circ} \mathrm{C}$ for $30 \mathrm{~s}, 55^{\circ} \mathrm{C}$ for $30 \mathrm{~s}$, $72^{\circ} \mathrm{C}$ for $30 \mathrm{~s}$; and finally $72^{\circ} \mathrm{C}$ for $5 \mathrm{~min}$.

Helicobacter genus-specific PCR products were sequenced, aligned and compared with the sequences from GenBank database using BLASTN 2.2.1 (http://blast. ncbi.nlm.nih.gov/Blast.cgi).

Total RNA was extracted by a RNeasy ${ }^{\circledR}$ kit (Qiagen), 100 ng of RNA was used for reverse strand cDNA synthesis according to the manufacturer's protocol (Quanti Tect ${ }^{\circledR}$ Reverse Transcription Kit, Qiagen).

Expression of IL-1 and IL-8 genes was quantified using real-time RT-PCR (LightCycler ${ }^{\circledR}$; Roche Diagnostic). $\beta$-glucuronidase gene (GUS) was used as reference (Romanowski et al., 2008).

The reaction mixture contained $(20 \mu \mathrm{l}): 2 \mu \mathrm{l}$ of cDNA, $5 \mu \mathrm{M}$ concentration of each primer, $3 \mathrm{mM}$ of $\mathrm{MgCl}_{2}$ and $2 \mu \mathrm{l}$ of ready-to-use Light Cycler ${ }^{\circledR}$ DNA Master SYBR Green I (Roche Diagnostic). The polymerase was activated at $95^{\circ} \mathrm{C}$ for $10 \mathrm{~min}$. The following cycling conditions were used in the reaction: $1 \mathrm{~s}$ (IL-1, IL-8) and $5 \mathrm{~s}$ (GUS) $95^{\circ} \mathrm{C}$ denaturation step, $15 \mathrm{~s}$ annealing at $64^{\circ} \mathrm{C}$ (IL-1, IL-8) and $60^{\circ} \mathrm{C}$ (GUS), and $20 \mathrm{~s}$ (IL-1, IL-8) and $10 \mathrm{~s}$ (GUS) extension at $72^{\circ} \mathrm{C}$. Melting-curve analysis followed 45 and 50 cycles of IL-1, IL- 8 and GUS genes amplification, respectively. Results were normalized with respect to the reference gene.

To determine expression levels of genes of interest in the studied samples, standard curves for IL- 1 and IL-8 were generated (serial dilutions of a standard sample used at this step were as follows: $1 \mathrm{x}, 0.5 \mathrm{x}, 0.2 \mathrm{x}, 0.1 \mathrm{x}$ ). As a standard we used a mixture of all cDNAs. Each sample was studied in three repetitions and normalized with respect to the reference gene.

The role of $H$. pylori in various gastric and duodenal diseases is well documented. In recent years $H$. pylori DNA has been identified in the bile, gallbladder and liver tissue of patients with different hepato-biliary diseases. Recently published detection rates of Helicobacter spp., in tissue samples collected from patients with liver cancer, varied from $0 \%$ to $100 \%$ (Avenaud et al., 2000; Nilsson et al., 2001; Verhoef et al., 2003; Huang et al., 2004; Ito et al., 2004; Rocha et al., 2005; Vivekanandan and Torbenson 2008). In our study we selected $16 \mathrm{~S}$ rDNA as the target because it contains both conserved and highly variable regions and gene sequences for almost all Helicobacter species available in public data bases. We identified Helicobacter genus-specific PCR products in 16/27 (59\%) of the liver specimens, which constitutes a more than 2 -fold increase of the detection frequency in comparison to the data previously published by our group (Stalke et al., 2005). The differences in detection level might be related to improvements in PCR reaction conditions. Previously only BSA was used to avoid the inhibitory effect of bile, whereas at present we used several PCR facilitators which improved the frequency of Helicobacter spp. DNA detection. Moreover, the amount of DNA per reaction, which we used as a template was $20 \mathrm{ng}$, whereas previously $5 \mu \mathrm{l}$ of each DNA solution was added, regardless of the concentration. Additionally, in the previously published study, diluted product from the first PCR reaction was used as a template in the second step, while here, we added undiluted product. All this differences could influence detection sensitivity.

The DNA sequence of 15 out of 16 (94\%) positive samples showed the highest similarity to $H$. pylori $16 \mathrm{~S}$ rRNA gene, whereas in 1 sample $(6 \%), H$. cetorum-like DNA was detected. Detailed chromatogram analysis 
revealed that 3 samples contained mixed DNA material. In those three samples $H$. rodentium-like DNA was identified based on double fluorescent signals in positions where the 16S rRNA genes differ for H.pylori and $H$. rodentium. This may indicate that in humans, different isolates of particular Helicobacter species may exist, like it was found in other species (Nilsson et al., 2004). In our recently published results we also found $H$. rodentium-like DNA by means of denaturing gradient gel electrophoresis (DGGE) and subsequent DNA sequencing (Nakonieczna et al., 2010). This H. rodentium-like DNA was actually the most prevalent one in the previously studied group of patients, which in comparison to the presented data was less heterogeneous.

Literature data indicate that expression levels of IL-1 and IL-8 are higher in gastric epithelial cells of $H$. pyloriinfected than in uninfected patients (Backhed et al., 2003). As the phenomenon of Helicobacter species presence in the human liver is widely discussed with respect to its participation in disease state and/or progression, we analyzed the level of IL- 8 and IL-1 in the group of patients, in which Helicobacter DNA was detected. As a control group, patients with negative result of nestedPCR were used. There were no differences in IL- 8 gene expression between Helicobacter-positive and Helicobacter-negative patients. The biopsy samples obtained from $H$. pylori-positive patients expressed about two times higher levels of IL-1, however this data was not statistically significant (Table I). Moreover, comparison of Helicobacter spp. positive and negative group did not show any statistically relevant differences in the functional liver test, including the levels of alanine aminotransferase, aspartate aminotransferase, $\gamma$-glutamyl transpeptidase, alkaline phosphatase, hemoglobin and bilirubin (Table I). However, we did not study the status of cytotoxin associated gene A ( $\operatorname{cag} A)$ in the Helicobacter-positive group, which might have influenced the results. It is known that $c a g A^{+}$strains are associated with enhanced secretion of interleukins, especially IL-8 (Backhed et al., 2003; Rieder et al., 2005). The relatively low expression level of the studied interleukins can be explained by defective immune system of investigated individuals or their general low immunity. Another interpretation might be low bacterial load and their adaptation to a special environment. Besides, the expression level of cytokines is associated with disease progression and is highly increased at the initial stage of disease. Because the investigated material originated from patients with chronic liver diseases we can suppose that levels of IL-1 and IL-8 were low.

Lack of significant differences in expression levels of studied genes may be associated with the fact that H. pylori possesses lipopolysaccharide (LPS) with a lower virulence compared to the typical bacterial endotoxins, such as Escherichia coli LPS. Furthermore, H. pylori adheres and is internalized into hepatocytes more efficiently than into gastric epithelial cells. It appears that H. pylori may survive inside hepatocytes and effectively avoid host response (Ito et al., 2008).

Sequence analysis showed that $H$. pylori is the most prevalent species (94\%) in the studied population. In contrast to gastric epithelial cells, the presence of $H$. pylori in the liver of patient with CLD had no influence on IL-8 and IL-1 mRNAs status as well as biochemical parameters describing liver functioning.

\section{Acknowledgments \\ This study was funded by University of Gdańsk, grant no B051-5- -0315-8 and Medical University grant no BW 155 and ST no 79.}

\section{Literature}

Al-Soud W.A., M. Bennedsen, S.L. On, I.S. Ouis, P. Vandamme, H.O. Nilsson, A. Ljungh and T. Wadström. 2003. Assessment of PCR-DGGE for the identification of diverse Helicobacter species, and application to faecal samples from zoo animals to determine Helicobacter prevalence. J. Med. Microbiol. 52: 765-771.

Avenaud P., A. Marais, L. Monteiro, B. Lebail, P. Bioulac Sage and C. Balabaud. 2000. Detection of Helicobacter species in liver of patients with and without primary liver carcinoma. Cancer 89: 1431-1439.

Backhed F., E. Torstensson, D. Seguin, A. Richter-Dahlfors and B. Rokbi. 2003. Helicobacter pylori Infection Induces Interleukin-8 Receptor. Expression in the Human Gastric Epithelium. Infection and Immunity 71: 3357-3360.

Huang Y., H.G. Fan, Z.M. Wang, J.H. Zhou, X.F. Tian and N. Li. 2004. Identification of Helicobacter species in human liver samples from patients with primary hepatocellular carcinoma. J. Clin. Pathol. 57: 1273-1277.

IARC Working Group on the Evaluation of Carcinogenic Risks to Humans. Shistosomes, liver flukes and Helicobacter pylori. Lyon: IARC monographs, 1994: 177-243.

Ito K., M. Nakamura, G. Toda, M. Negishi, A. Torii and T. Ohno. 2004. Potential role of Helicobacter pylori in hepatocarcinogenesis. Int. J. Mol. Med. 13: 221-227.

Ito K., Y. Yamaoka, H. Ota. 2008. Adherence, Internalization, and Persistence of Helicobacter pylori in Hepatocytes. Dig. Dis. Sci. 53: 2541-2549.

Nakonieczna J., P. Stalke, W.A. Al-Soud, T. Wadström and K.P. Bielawski. 2010. Detection of Helicobacter rodentium-like DNA in the liver tissue of patients with chronic liver diseases by polymerase chain reaction-denaturing gradient gel electrophoresis and DNA sequence analysis. Diagn Microbiol Infect Dis. 68: 201-7. Nilsson H.O., R. Mulchandani, K.G. Tranberg. 2001. Helicobacter species identified in liver from patients with cholangiocarcinoma and hepatocellular carcinoma. Gastroenterology 120: 323-324.

Pellicano R., A. Ménard. 2008. Helicobacter species and liver diseases: association or causation? Lancet Infect Dis. 8: 254-60.

Rieder G., W. Fischer. 2005. Interaction of Helicobacter pylori with host cells: Function of secreted and translocated molecules. Curr. Opin. Microbiol. 8: 67-73.

Rocha M., P. Avenaut, A. Menard, B. Le Bail, C. Balabaud and P. Bioulac-Sage. 2005. Association of Helicobacter species with hepatitis C cirrhosis with or without hepatocellular carcinoma. Gut 54: 396-401. 
Romanowski T., K. Sikorska and K.P. Bielawski. 2008. GUS and PMM1 as suitable reference genes for gene expression analysis in the liver tissue of patients with chronic hepatitis. Med. Sci. Monit. 14: 147-152.

Stalke P., W.A. Al-Soud, K.P. Bielawski, A. Bakowska, H. Trocha and J. Stępiński. 2005. Detection of Helicobacter species in liver and stomach tissue of patients with chronic liver diseases using polimerase chain reaction-denaturin gradient gel electrophoresis and immunohistochemistry. Scand. J. Gastroenterol 40: 1032-1041.
Verhoef C., R.G. Pot, R.A. de Man, P.E. Zondervan, E.J. Kuipers, J.N. Ijzermans and J.G. Kusters. 2003. Detection of identical Helicobacter DNA in the stomach and in the non-cirrhotic liver of patients with hepatocellular carcinoma. Eur. J. Gastroenterol. Hepatol. 15: 1171-1174.

Vivekanandan P. and M. Torbenson. 2008. Low frequency of Helicobacter DNA in benign and malignant liver tissues from Baltimore, United States. Human Pathology 39: 213-216.

Wedi B. and A. Kapp. 2002. Helicobacter pylori infection in skin diseases: a critical appraisal. Am. J. Clin. Dermatol. 3: 273-282 